\title{
Kālighāt and Ritual Purity in Kolkata: A Historical Approach to Generations in India
}

\author{
Mario I. Aguilar \\ School of Divinity, University of St. Andrews, St. Andrews, UK \\ Email:mia2@st-andrews.ac.uk
}

How to cite this paper: Aguilar, M. I. (2019). Kālighāt and Ritual Purity in Kolkata: A Historical Approach to Generations in India. Sociology Mind, 9, 114-126. https://doi.org/10.4236/sm.2019.91007

Received: September 5, 2018

Accepted: January 8, 2019

Published: January 14, 2019

Copyright $\odot 2019$ by author(s) and Scientific Research Publishing Inc. This work is licensed under the Creative Commons Attribution International License (CC BY 4.0).

http://creativecommons.org/licenses/by/4.0/

\begin{abstract}
Mother Teresa of Kolkata remains one of the adopted figures of the old Indian capital in that after her arrival to be a teacher in a well-to-do school in Kolkata she took to the slums and the service of the "poorest of the poor" within an independent India. While there are several works published about her life after she opened Nirmal Hriday Ashram, a home for the destitute and the dying in Kolkata, less has been researched on the female Hindu symbolic associations of Kolkata with the feminine, as well as the challenges that Mother Teresa faced when as a Christian and as a woman decided to open Nirma Hriday Ashram. This paper examines the significance of Kālighāt for Kolkata and Hinduism and the issues of (in) purity that were triggered by Mother Teresa's opening of a place for the dying within a property that previously was part of the Kālighāt. This paper suggests that a socio-historical understanding of Kolkata is central to any understanding of the work of the Missionaries of Charity in Kolkata in later periods and their ongoing cooperation with Hindus and Muslims within Kolkata. Thus, ritual purity is not an isolated understanding within a synchronic moment but a generational challenge to ongoing diachronic changes within the City of Kolkata.
\end{abstract}

\section{Keywords}

India Kolkata, Kālighāt, Mother Teresa of Kolkata, Nirmal Hriday Ashram, Problem of Generations, Sociology of Religion, Hinduism, Catholic Church

\section{Introduction}

In 1952, Mother Teresa of Kolkata, opened a place for those dying in an empty house for pilgrims, devotees to Khali, beside the Kālighāt Temple in the then Calcutta. Protests and attacks on Mother Teresa by Hindu devotees followed. They felt that the presence of Mother Teresa was an attack on the goddess and 
on Hinduism by Christians. However, with the help of the Calcutta Corporation Mother Teresa managed to continue welcoming the dying of Kolkata for their last days on earth, founding Nirmal Hriday. This paper examines the socio-historical diversity of ritual cleanness and dirt within this neighbourhood and in the context of Kolkata. The history of the city, the capital of British India until 1911, remains a diverse and rich canopy of socio-historical perceptions by diverse generations: Those that lived in the city before the arrival of Mother Teresa and who experienced the Bengal famine (1943), the Partition of India and of Bengal (1947), the violence that followed Partition and the subsequent creation of Bangladesh out of East Pakistan (colonial West Bengal) in 1971. This paper argues that different generations with a different ethos have constructed different perceptions of meaning within Kolkata, and that what is pure for some is dirt for others, following Mary Douglas' work Purity and Danger. Generations in this paper, are not biological sets of peers born in the same period, but they are following the sociology of Karl Mannheim (Mannheim, 1952) groups that share the same ethos and can be of different ages, backgrounds, and sets of kinship patterns. The paper concludes that sociological approaches to the study of violence and impurity within the sociology of religion can only be enriched by the inclusion of socio-historical and diachronic methodologies within a synchronic generational social analysis. Thus, the sociology of religion cannot be only a functional understanding of cohesiveness and shared symbolic meanings but also an ongoing clash of different ethos, ways of relating, and socio-structural oppositions.

\section{Kālighāt and Mother Teresa}

It was in 1952 that Mother Teresa who had already experienced the atrocities of Partition in Bengal experienced further the suffering of the poor of Kalkota. A naked young beggar of 13 or 14 years of age died stretched on the road in a Kolkata residential area. He had lied emaciated and ill on the road until somebody called an ambulance. He was brought to hospital but as he was naked it was assumed that he didn't have the means to pay for medical treatment. Thus, he was brought back to the same place where he was found to die alone. The incident was reported in the Kolkata press, outlining a phenomenon that was common within the city. Mother Teresa already aware of the problem had helped a few of those cases comforting them before death. Subsequently, she applied to the municipal authorities for a house where she could host the dying before their death so that they could die with dignity (Spink, 2011: p. 53). She was granted a monthly sum of money as well as the use of some pilgrims' dormitories attached to the Kali Temple where pilgrims had some rest beside the ghats where bodies were cremated (Spink, 2011: p. 54).

The neighbourhood of Kālighāt in Kolkata is one of the oldest neighbourhoods in South Kolkata. It is a multicultural place due to the many incursions and immigrations into the city. Its main feature within Hindu ritual history is 
the existence of the Kălighāt Kali Temple with its many associations to the life of the city and the history of Hinduism and pilgrimage to the sacred waters in Kalkota (for those varied layers of meaning and discourse see Moodie, 2014, and Roy, 1993). The temple constitutes one of the 52 Shakti Peethas, main shrines and pilgrim destinations in Shaktism, a tradition in Hinduism in which the metaphysical energy is feminine and the goddess (Devi) is supreme. Further feminine manifestations within Shaktism include Lakshmi and Kali, and feminine manifestations associated with Shiva, Brahma or Vishnu.

The origin of the Shakthi Peethas and the destruction of Daksha's sacrifice relates to Sati (Dakshayani), the wife of Shiva and the daughter of Daksha Prajaapati, a descendant of Brahma. Daksha Prajaapati or the keeper of beings in Hinduism had several daughters, including Sati, an incarnation of the Primordial Mother Goddess or Shakthi. She was married to Shiva, the ascetic who lived in the snows of the Kailasa Parvat. The Kailasa Parvat is still today a place of pilgrimage for Hindus and Buddhists in Tibet (Panikkar \& Carrara, 2018). Daksha had not approved of such marriage because Shiva was penniless rather than a wealthy king. Daksha organised a gathering of all divine beings, but he decided not to invite Shiva. However, Sati arrived unexpectedly and hearing the insults to Shiva she immolated herself. Shiva was extremely upset and started the Tandav or dance of destruction with the body of Sati calming down only when Vishnu chopped Sati's body into 51 pieces that fell over India (today Pakistan and Bangladesh as well). Thus, since then Shakti Peetas are considered divine seats of Shakthi or the Primordial Mother Goddess which are located where pieces of Sati's body had fallen.

Each of the 51 Shakthi Peetas had a temple dedicated to the Shakthi or the Primordial Mother and a temple dedicated to the Bhairava or Shiva, the All-Father, marking the places where Shaivism and Shaktism united. Such understanding is that male and female are united with the absolute need of one and the other. At the Khāligāt it is assumed that the right toes of Sati fell there while some Puranas also mention that the Mukha Khanda or the face of the goddess was fossilised, and it is worshipped at the Khāligāt (for the Kalika Purana Asthashakti that describe the major Shakthi Peetas see the hymn "Vimala Pada khandancha").

The first encounters between the East India Company and the Hindu of Calcutta within the formation of the British Raj brought a ritual purity threat by Europeans to Kolkata as a sacred abode of the Mother Goddess. This threat was only resolved by the colonial masters with the imposition of colonial rule between 1848 and 1947 (on Calcutta see Bhattacharyya, 2018). Thus, Mother Teresa in her own challenges within Kolkota had to deal with a sacred city that had been the centre of the British Raj as well as a place where the 1943 famine and the Partition of 1947 had left deep social scars of suffering and division within a sacred and pure place of pilgrimage for Hindus. By the time that Mother Teresa started work in Kolkata a certain lack of social concern for the dying had arisen out of a Hindu belief in a reincarnation but also by people who had experienced 
British colonial policies that had preferred not to feed Bengal during Wold War II.As a port and an urban city Kolkota was the destination of destitute men, women and children without families and the events that preceded Partition left the mark in a city where hunger, disease and poverty were also part of a beautiful colonial enclave. Thus, by the time that Mother Teresa arrived in Kolkata social services in the City were not able to cope with the human demand of housing and food that followed a period of famine as well as a period of unrest and violence after Partition. An exploration of such processes could aid our understanding of the moment post-Partition in which Mother Teresa started her work at the slums and in which she founded Nirmal Hriday.

Mother Teresa was a witness to the killings and the torching of homes that preceded Partition in 1947 and that followed after the Partition of Bengal with thousands of refugees moving into Kolkata trying to avoid their residence within the newly created East Pakistan. The killings followed fear on all sides about the fate of families, particularly women and their purity, and therefore the honour of families and kin. In my work on Partition I have outlined the need to understand the need for purity on women and their wombs because in such wombs the future Hindus or Muslims are conceived and then when they are born they represent the continuity of a family and the honour of families bestowed upon women and kept within the womb (Aguilar, 2018: Chapter 2). I have argued that "after rape, the different gods were dislocated from their shrines and those who were born from an ethnic womb became part of a community with different rites and obligations. They were re-branded and re-appropriated by force creating the social separation of ethnic groups but also the segregation of gods within India and Pakistan" (Aguilar, 2018: p. 73).

In her analysis of purity, Mary Douglas has argued that "the only way in which pollution ideas make sense is in reference to a total structure of thought whose keystone, boundaries, margins and internal lines are held in relation by rituals of separation" (Douglas, 2002: p. 51). The arrival of Mother Teresa takes place after the Calcutta council decides that she can have a property used by pilgrims to the Kāalighat to rest because she will be able to aid the council with the major problem of dying peoples on the streets abhorred by residents as polluting their neighbourhoods. The council clerk in-charge of the paperwork, the corporation health officer, was a Muslim deciding on the use of what it had been council property for the use of Hindus (Spink, 2011: p. 54). Thus, a Christian symbolically occupied a Hindu space, namely two rooms and corridor, to aid Hindus, Muslims and Christians alike. However, on her arrival Hindus threw stones at her and her companions, because they felt that their ritual space had been in the words of Douglas "defiled". The defilement of abomination is the possibility of ritual pollution that brings with it the non-belonging and social rejection. Mother Teresa could have been associated with a Christian organisation or even with the remnant of a European empire, but she was in reality not associated with colonial or post-colonial institutions. She resided in the slums alone and was helped later by her former school students who were still Hindus until a 
few of them joined the Missionaries of Charity and were rejected by their families because of their conversion to Christianity.

What were the rites of separation that Mother Teresa implemented? She brought social dirt to a place that was changed from a Hindu place of rest to a state property belonging to all and then to a consecrated Christian place because of the arrival of the tabernacle and the presence of Jesus in the Eucharist. However, the fear by Hindus around the Kālighāt was that Mother Teresa would start trying to convert Hindus. Such understanding made sense from a Hindu point of view and a general experience of the British presence in India where the religion of establishment was Christianity. The same fears were developed years later when in Varanasi members of the Missionaries of Charity were to take publicly their vows as consecrated religious sisters and Mother Teresa had to explain publicly that they were not trying to upset any established order of purity and reincarnation at the eternal city of the Hindus.

For Mother Teresa, Nirmay Hrimay, a "Place of the Immaculate Heart", was a very suitable place beside a temple revered by Hindus and in which those aided by the Missionaries of Charity could rest before they went to heaven (Spink, 2011: p. 54). Cots were placed on the floor and dimmed lights installed so that the terminally ill rejected by their families and considered impure because of disease by most of the population could die with dignity. Rites were organised for the dying so that Hindus were given water from the Ganges on their lips, Muslims were recited the Koran, and for a minority Christians the last rites were organised (Spink, 2011: p. 55). However, as noted by her biographer "there was nevertheless a considerable amount of hostility toward the foreign woman and her companions, who were considered to be encroaching on Hindu territory with the cooperation of a Muslim health officer" (Spink, 2011: p. 55). There was a threat to kill Mother Teresa, threat that gave more significance to their work, and a group of women also came in protesting against Mother Teresa until they saw the care given to the dying and suggested that they could only be evicted if others within the Hindu community would take their place. The best example that settled matters was the care of a Hindu priest by Mother Teresa who had found him very ill on the streets and who cared personally for him without any hesitation. Another Hindu priest from the Kālighāt made the following comment: "We worship a Kali made of stone but this is the real Ma-Kali, a Kali of flesh and blood" (Spink, 2011: p. 56). Even when it was agreed by the council after many complaints that if another place were to be found the home for the dying would be moved there this never happened. On the contrary, the home for the dying became a place where Hindu pilgrims stopped to make offerings and who requested the blessing and prayers of Mother Teresa. Very quickly Hindu ladies were the ones washing the dying and cutting their hair.

If one returns to Mary Douglas analysis she made the distinction between dirt because of lack of hygiene as in a European concept of what it is to be cleaned and, in the socio-symbolic or religious sense where dirty means unclean in a symbolic category. Thus, "dirt is the by-product of a systematic order and classi- 
fication of matter, in so far as ordering involves rejecting inappropriate elements" (Douglas, 2002: p. 44). Thus, for Hindus at the Khāligāt the body of a dying or a dead person was to be feared because contact with dead bodies was the realm of the untouchables within the Hindu caste and not the realm of those who were pilgrims to the temple. Therefore, Mother Teresa was not only a polluting person coming from another religion and who had drunk the waters of other household, but she was also a person who had touched the dead becoming symbolically an outcast, a person who in turn would pollute others. It is within this symbolic category of cleanness/holiness and dirtiness/exclusion that those Hindus who got to know her admired her strength as to become an outcast for others rather than to remain a European woman outside the realms of a Hindu non-belonging of outcasts. Not only women could not touch males who were not kin but those who touch a corpse needed purification: "those who touch the corpse are purified in ten days, but those who offer libations in three. A pupil who performs the funerary rites of his deceased teacher, on the other hand, is on par with those who carry a corpse and is purified in ten days" (Mānava Dharmaśāstra V. 64-65).

\section{The Silencing of Bengal (1943)}

Some colonial policies under the pressure of War World II created, and rightly so, the image of the British as ready to leave people to die if they had to feed their own. Thus, the famine in Bengal in 1943 accelerated discontent not only at the political level but also at the level of cultural movements by artists and others, particularly triggered by the work of Chittaprosad and other artists, members of the Communist Party of India.

The 1943 famine in Bengal was a man-made disaster, a "catastrophe of distinct significance" already recognized as such by 23 September 1943 (Mallik, 2011: p. I, 21). The disaster arose out of the association of India with Britain in World War II and the need for resources and supplies that British India provided to the war effort (Batabyal, 2005; Mukerjee, 2010; Mukherjee, 2015; Stevenson, 2005; Venkataramani, 1973). The fall of Rangoon to the Japanese cut the rice supply from Burma and the 1942 "Quit India" call hardened the position of the British colonial power towards the local population of Bengal (Great Britain: Foreign and Commonwealth Office, IV, 1973). To make matters worse, a cyclone hit the coast on 16 October 1943 and the villages and lands that had been protesting against the British and their policies. The colonial administration blamed the lack of grain availability for the famine, but Dr Amartya Sen has made clearly the point that the crops of 1943 were larger than those of 1941 when there was no famine (Sen, 1981). For Sen there were complex issues associated with the famine rather than solely a lack of grain production. A short review of some of the archives of the time suggests that the policy of feeding India was collapsing and was not adequate. Thus, Lt. Col. Sir John Herbert (Governor of Bengal) wrote to the Viceroy of India, stating that "the Basic Plan contemplated sending an agreed total of nearly 370,000 tons of rice to Bengal over a pe- 
riod of a year to be reckoned from December 1942. Actually, in the 7 months December 1942 to June 1943 only a little over 44,000 tons reached Bengal" so that Sir J. Herbert concerned himself with the food situation in Bengal and requested for the Central Government to control of food grains (Sir J. Herbert [Bengal] to the Marquess of Linlithgow, Government House, Calcutta, 2 July 1943 MSS. EUR. F. 125/43).

The end of the British Raj in India coincided with the end of World War II because by then Britain needed to reconstruct a home country destroyed by war and the efforts in India could not take priority over the post-war efforts at home. The cries for self-rule in India had continued throughout the war, particularly with the fear that India had been dragged into the war by the colonial power without any consultation and that India could be attacked by Britain's enemies at any time. However, as the war ended, and a new British government was elected led by the Labour Party it was clear that a post-war Britain was not going to be able to continue its complex human and economic involvement in India (Mahajan, 2000; Panigrahi, 2004). Thus, after thirty years of Indian strife for independence Britain decided to hand over power in 1948, a date that was quickly move forward to August 1947. Lord Mountbatten was put in charge of British India and in June 1947 an agreement was reached between the Muslim League and the Indian National Congress to create a new state called Pakistan. The term had been developed in the early 1930s and while it had all the makings of a need for a greater Muslim homeland, it also had the worrying connotation of "the land of the paks"- "the spiritually pure and clean". The name "Pakistan" had been firstly adopted in the 1930s by a group of Muslims at Cambridge to encompass a fictitious greater Muslim homeland consisting of P (unjab), A (fghania, i.e. the North West Frontier), K (ashmir), I (ran), S (ind), T (urkharistan), A (fghanistan) and (Baluchista), N (Keay, 2001: p. 496). Pakistan would eventually be the product of the partition of the Punjab and British India less part of the Punjab was to be called India. Suggestions to call independent India as Hindustan were finally rejected. In June 1947, a "Partition Council" was formed with the task of dividing all assets of the Government of India, assets that included "everything from railway lines, food stocks, ships and bulldozers to printing presses, chairs and typewriters" (French, 1998: p. 314; Sengupta, 2014). In July 1947, the British Parliament passed the India Independence Act and at midnight of the 14 August and from the 15 August constitutional authority to India and the newly formed Pakistan was given (Khan, 2007; Talbot, 2007).

The two events, the transfer of power and Partition, became engraved events in the soul of India, so that together with freedom there was what Jadeja has called a "vivisection on the communal basis" (Jadeja, 2015). Such tragic event created an ambivalent memory either of independence or of tragic events. However, as soon as thing got out of hand silence started to reign because the reality was that the number of killings and rapes were enormous and that both Hindus and Muslims were involved. Gandhi's dream of a united secular India had collapsed because the secular in Hinduism had meant the possibility of a society in 
which all religions and philosophies could co-exist. In a talk with Y. M. Dadoo and O. M. Naicker, the Mahatma spoke as follows: "India is now on the threshold of independence. But this is not the independence I want. To my mind it will not be independence if India is partitioned and the minorities do not enjoy security, protection and equal treatment" (Mahatma Ghandi, Talk with Y. M. Dadoo and O.M. Naicker (G.) Biharni Komi Agman, 187. MPWMG, vol. III, 268-269 [Brown, 2008: $\$ 135,160]$ ). Further writings by Gandhi on the political unity in religious diversity expressed the same sentiment (Iyer, 1986-1987). Gandhi's assassination in 1948 became the first state occasion in which the secular was enforced, and Partition silenced in its totality. Thus, for Mira Debs "Gandhi's assassination cemented his representation as an Indian icon, part of a broader project to develop unifying and hence secular symbols for the new nation" (Debs, 2013: p. 641).

\section{Forced Migration and Silence}

Gandhi had opposed partition against the British judgement that stated that if the Muslims were left within India there would be a civil war. At the start of the negotiations for Indian independence, the Indian Muslim League leaders M.A. Jinnah and Liaqat Ali Khan could not agree with the Indian Congress leaders Pandit Nehru and Sardar Patel. After independence their deaths did not help matters as M. A. Jinna died of tuberculosis in 1948, and Liaqat Ali Khan who became Pakistan first prime minister was assassinated by Sed Akbar, a Muslim, in 1951. According to Bal K. Gupta, at the time of the partition the total population of undivided India was four hundred million of which circa three hundred million became part of secular India and one hundred million formed Islamic Pakistan (Gupta, 2012: p. xxii). Of those in India 15\% were Muslims and 20\% of those in Pakistan were Hindus and Sikhs (Gupta, 2012: p. xxii). Those who needed to move because they were in the wrong side of the new map due to their ethnicity and religion were circa fifteen million that constituted the larger number of migrants in history to be moved together within a short period of time (Gupta, 2012: p. xxii). Pakistan was formed with the five Muslim majority provinces: West Punjab, Sindh, Balochistan, North Western Frontier (NWFP) and East Bengal. East Bengal, that is East Pakistan, was separated from West Pakistan by 1200 miles of Indian territory. Thus, Pakistanis who had to travel from one part to the other crossed 2000 miles by sea. In 1971, and after an armed conflict between East and West Pakistan, East Pakistan became independent as the Republic of Bangladesh.

Violence between Muslims and Hindus had started already in 1946 after the general elections in which Jinnah and the Muslim League had taken $90 \%$ of the seats allocated by the electoral system to Muslims. Jinnah wanted the protection of Muslims fearing that they would be discriminated by Hindus when the British left. The British did not agree with any partition of India and therefore Jinnah proclaimed 16 August 1946 as Direct-Action Day. Jinnah's intention was to put pressure on the British to give autonomy to Muslims rather than to leave Mus- 
lims in British India under the ruling of Hindus. Gandhi's views were ignored with enormous respect from 1946 to 1947, year in which Rear-Admiral Viscount Mountbatten of Burma, Viceroy of India, prepared the announcement of transfer of power on 3 June, with a series of meetings in which political and civil leaders were consulted about the possibilities and consequences of different plans for Partition (Mansergh, 1982). Mountbatten had prepared two different speeches, one of them to be broadcasted on 3 June 1947, one referring to the partition of Bengal, another with a unified Bengal included (Minutes of Viceroy's Thirty Fourth Staff Meeting, Items 1-7, Mountbatten Papers, in Mansergh and Moon $1982 \$ 1$ ). Thus, for example, on 31 May 1947 at 11am Mountbatten conducted the Thirty-Fourth Staff Meeting at the Viceroy's House in New Delhi, and the issue of Gandhi's opinions were discussed (Minutes of Viceroy's Thirty Fourth Staff Meeting, Items 1-7, Mountbatten Papers $\$ 2$ ). Present at the meeting were The Viceroy, Sir J. Colville, Lord Ismay, Sir E. Mieville, Mr Abell, Rao Bahadur V. P. Menon, Captain Brockman, Mr I.D. Scott, Mr Campbell-Johnson and Lieutenant-Colonel Erskine Crum. Within Item 4 of the minutes it is reported that Rao Bahadur Menon conveyed Sardar Patel's opinion to the effect that "not too much account should be taken of the recent utterance of Mr Gandhi in favour of a united India" (Minutes of Viceroy's Thirty Fourth Staff Meeting, Items 1-7, Mountbatten Papers $\$ 4)$. Gandhi’s utterances had been reported in The Times of India of $30^{\text {th }}$ May 1947: "Since his return to New Delhi five days ago, Mr Gandhi has, every evening, at his prayer meeting, preached against 'vivisection of the motherland' in terms disquietingly militant" (Mansergh, 1982: Footnote 5 at p. 5). In The Times of India of $31^{\text {st }}$ May 1947 there was a report on the previous evening prayer meeting led by Gandhi in which he had declared after the prayer meeting: "I made it clear yesterday that if I had my will there would never be Pakistan before peace, and certainly not through British intervention" (Mansergh, 1982: Footnote 5 at p. 5). Mountbatten had asked his attaché during the meeting of his staff on 31 May 2017 to note in an aside of his speech of 3 June 1947 pointing "to his basic agreement with Mr. Gandhi that the partitioning of India was wrong" (Minutes of Viceroy's Thirty Fourth Staff Meeting, Items 1-7, Mountbatten Papers $₫ 1$ ). Within the discussion Mountbatten reiterated his wish to make a remark on Gandhi's dissent regarding Partition but he agreed that Gandhi's position regarding a British imposition of a united India could not be sustained as any constitutional handover of India needed to be agreed by the consensus of all parties involved (Minutes of Viceroy's Thirty Fourth Staff Meeting, Items $1-7$, Mountbatten Papers $\$ 4$ ). By then Mountbatten had informed the governors of Punjab, Bengal and Assam that their provinces would be subject to a constitutional partition (Rear-Admiral Viscount Mountbatten of Burma to all Provincial Governors Telegram, R/3/1/150: ff 132-134, New Delhi 31 May 194711.50 pm). At $\S 15$ Mountbatten wrote: “To Governors of the Punjab, Bengal and Assam only). We must go ahead once with provisional administrative plans for partition and I will telegraph shortly about this." 


\section{Ritual Purity in India}

It is a fact that ritual purity was of the essence in the history of India because communities were either Muslim or Hindu, therefore even after the arrival of the British there were challenges to landscapes and spaces of ritual purity within British India. For example, one of the major challenges by the colonial authority was the allocation of water within the new limits by the colonial administration because women became polluted if they drank from the waters of a different community. Women were the keepers of the water within the home making sure that such water had been taken from the proper well and women were also the ones who kept the fire and the Hindu shrine with water, flowers, incense and fire within the home. If women became polluted their whole extended family became polluted because they carried the purity of the family and their descendants within their womb and they also socially and within the public sphere carried the honour of the family. Thus, while the seclusion of women resembled a complete patriarchal injustice, women had the power of the home in which ritual purity, oral traditions, and the sense of a family was kept always. Even when it was at Partition that people killed because of the pollution of water within new colonially assigned territories the issue of purity had been central to issues of conversion to Christianity, inter-marriage, and the inclusion/exclusion of family members and those who married into a large extended family. For example, Sundar Singh, a Sikh convert to Christianity, could not stay with his biological family after conversion to Christianity because he had become impure and would pollute the whole family if he stayed with them (Aguilar, 2017: pp. 42-43).

Purity was different between Hindus and Muslims and between different groups within the Hindu caste system, and therefore a sense of purity created divisions and sub-divisions within villages and local populations. If Hindus, Muslims and Sikhs lived in peace with each other with the occasional flare of violence it was because after years of negotiations they had managed to settle those boundaries of purity, including the water sources that belonged to different traditions. Partition unsettled those boundaries by moving people from their already acquired ritual boundaries. Therefore, Partition can be described as a movement of lines on the map by the British and by the destruction of symbolic and ritual boundaries of purity as a result. If purity was to be the foundation of the new post-Partition India such purity needed to be negotiated and in those delicate negotiations the social fear of pollution, of a disorderly and unhappy life, led Hindus, Muslims and Sikhs to fight for their rights and their purity in very uncertain and traumatic times imposed upon the population of British India by the transfer of power of 1947. However, the discussions on the transfer of power and the challenge to the British had already started years before, and particularly in the peripheries of Bengal and Punjab.

Generations in India were marked by Partition and by their experience of a violent transition between British India into an independent nation. Generations in India need to be explored not as grandparents, parents, and children but as 
social classifications that not only include the household and its ritual purity but the experience of Partition in so far as religion and ethnicity became the main classificatory devise for the development of an independent India. It was Mother Teresa that broke the ranks of caste and history in order to serve the poorest of the poor regardless of their position in society and a society deeply marked by Partition.

\section{Conclusions: Generations and the Perceptions of Danger}

Due to migrations, conquest, famine, Partition, and independence ritual laws and ritual purity within Kolkata needed to be reassessed so that the feminine side of the Goddess of the Kālighāt and even the foreign conquerors and missionaries such as Mother Teresa could be accommodated within a variety of ritual existences in the City. Purity remains a central point of understanding for all those who live in Kolkata and to start her aid to the "poorest of the poor" Mother Teresa had to be re-understood by all around her. From being a European teacher, she became a liminal figure touching corpses until she became a citizen and therefore was accepted within her ritual liminality and her Christian purity in a Hindu setting. However, in negotiating Christian charity she aided the negotiation of a diversified Kolkata that through different generations has been interpreted symbolically in very different manners.

Returning to Karl Mannheim's “problem of generations” I return to the problem of the sociology of Kolkata and of Mother Teresa. For Mannheim, generations are not biological repetitions of others over a period, but they operate in a locational manner whereby the experience of each generation is limited to a certain part of the historical process of a people (Mannheim, 1952). Others challenge such generational experience because there is a common ethos that binds them. Within the many social experiences of generational location in Kolkata the experience of ritual purity was challenged by Mother Teresa. Thus, a common experience arose within the city providing the possibility of an ongoing interreligious dialogue between those dying and those who cared for them. Christians, Hindus and Muslims who previously would have not worked together because of the limitations of purity and cleanliness interacted together in spaces set apart by Mother Teresa. Mother Teresa not only rejected the possibility of unchanging dirt, but she also fostered the possibility that the Mother Goddess was indeed looking after those who were at the Kālighāt, including those at Nirmay Hrimay, under her care.

\section{Conflicts of Interest}

The author declares no conflicts of interest regarding the publication of this paper.

\section{References}

Aguilar, M. I. (2017). The Way of the Hermit: Interfaith Encounters in Silence and 
Prayer. London and Philadelphia: Jessica Kingsley.

Aguilar, M. I. (2018). Interreligious Dialogue and the Partition of India: Hindus and Muslims in Dialogue about Violence and Forced Migration. London and Philadelphia: Jessica Kingsley.

Batabyal, R. (2005). Communalism in Bengal: From Famine to Noakhali 1943-47. New Delhi: Sage Publications India.

Bhattacharyya, D. (2018). Empire and Ecology in the Bengal Delta: The Making of Calcutta. Cambridge: Cambridge University Press. https://doi.org/10.1017/9781108348867

Brown, J. M. (Ed.) (2008). Mahatma Gandhi: The Essential Writings. Oxford: Oxford University Press.

Debs, M. (2013). Using Cultural Trauma: Ghandi's Assassination, Partition and Secular Nationalism in Post-Independence India. Nations and Nationalism, 19, 635-653. https://doi.org/10.1111/nana.12038

Douglas, M. (2002). Purity and Danger: An Analysis of Concept of Pollution and Taboo. London and New York: Routledge.

French, P. (1998). Liberty or Death: India's Journey to Independence and Division. London: Flamingo.

Great Britain: Foreign and Commonwealth Office (1973). Transfer of Power in India, 1942-47: Bengal Famine and the New Viceroyalty, June 15, 1943-August 31, 1944, Constitutional Relations between Britain \& India, Vol. 4. London: Stationary Office Books.

Gupta, B. K. (2012). Forgotten Atrocities: Memoirs of a Survivor of the 1947 Partition of India. Raleigh, NC: Lulu Enterprises.

Iyer, R. N. (Ed.) (1986-1987). The Moral and Political Writings of Mahatma Gandhi, 3 Volumes. Vol. I: Civilization, Politics, and Religion, 1986. Vol. II: Truth and Non-Violence, 1986. Vol. III: Non-Violent Resistance and Social Transformation, 1987. Oxford: Clarendon Press.

Jadeja, K. D. (2015). The Partition of India and Its Reflections in Khushwant Singh's Train to Pakistan and Bapsi Sidhwa's Ice Candy Man: A Comparative Study. Holos, 3, 415-419. https://doi.org/10.15628/holos.2015.2814

Keay, J. (2001). India: A History. London: HarperCollins, and New Delhi: HarperCollins India.

Khan, Y. (2007). The Great Partition: The Making of India and Pakistan. New Haven, CT: Yale University Press.

Mahajan, S. (2000). Independence and Partition: The Erosion of Colonial Power in India. New Delhi: Sage Publications.

Mallik, S. K. (2011). Chittaprosad: A Retrospective 1915-1978(2 Vol.). Delhi Art Gallery.

Mannheim, K. (1952). The Problem of Generations. In P. Kecskemeti (Ed.), Essays on the Sociology of Knowledge (pp. 276-320). London: Routledge and Kegan Paul.

Mansergh, N. (1982). Constitutional Relations between Britain and India, the Transfer of Power 1942-47. Volume XI: The Mountbatten Viceroyalty-Announcement and Reception of the 3 June Plan, 31 May-7 July 1947. London: Her Majesty's Stationery Office.

Moodie, D. (2014). Contesting Kālīghāt: Discourse Productions of a Hindu Temple in Colonial and Contemporary Kolkata. Harvard Theological Review, 107, 501-502.

Mukerjee, M. (2010). Churchill's Secret War: The British Empire and the Forgotten Indian Famine of World War II. New York: Basic Books. 
Mukherjee, J. (2015). Hungry Bengal: War, Famine and the End of Empire. New York: Oxford University Press. https://doi.org/10.1093/acprof:oso/9780190209889.001.0001

Panigrahi, D. N. (2004). India's Partition: The Story of Imperialism in Retreat. London: Routledge. https://doi.org/10.4324/9780203324882

Panikkar, R., \& Carrara, M. (2018). Peregrinación al Kailasa y al centro de uno mismo. Barcelona: Ediciones Luciérnaga.

Roy, I. B. (1993). Kalighat: Its Impact on the Socio-Cultural Life of Hindus. New Delhi: Gyan Publishing House.

Sen, A. (1981). Poverty and Famines: An Essay on Entitlement and Deprivation. Oxford: Clarendon Press.

Sengupta, A. (2014). Breaking Up: Dividing Assets between India and Pakistan in Times of Partition. Indian Economic and Social History Review, 51, 529-548. https://doi.org/10.1177/0019464614550767

Spink, K. (2011). Mother Teresa: An Authorized Biography. New York: HarperOne.

Stevenson, R. (2005). Bengal Tiger and British Lion: An Account of the Bengal Famine of 1943. Lincoln: iUniverse.

Talbot, P. (2007). An American Witness to India's Partition. Thousand Oaks, CA: Sage Publications.

Venkataramani, M. S. (1973). Bengal Famine of 1943: The American Response. Noira: Vikas Publishing House. 